\title{
Raising Pragmatic Awareness through Teacher Illocutionary Acts
}

\author{
Evangelia Michail \\ Aristotle University of Thessaloniki \\ michaileva@yahoo.com
}

\section{Abstract}

This case study is a pedagogical intervention in the teaching of pragmatics in the Greek EFL classroom, aiming to redefine the classroom as a curricular space (Graves 2008), exploring it as a source of input in order to raise students' pragmatic awareness. The theoretical assumption is that explicit pragmatic awareness on the part of students will enhance the overall learning process. In this study, particular emphasis is placed on the illocutionary force of teacher questions. Adopting the framework of Exploratory Practice, it takes the notion of research as a supportive rather than as a parasitic activity (Allwright 2005), thus carrying out research via normal classroom activities, engaging 22 upperintermediate students as co-researchers. Data collection was carried out by monitoring lessons (video-recording and reflective lesson plans), reflecting on students' choices, and reflecting on students' reflections.

The findings of this study are positive, even if preliminary, corroborating our working hypothesis that we can raise learners' pragmatic awareness on condition that we adhere to Austin's suggested moral to "engage in elucidating the total speech act in the total speech situation" (1962: 147).

\section{Introduction}

Raising learners' pragmatic awareness has become one of the main goals in the EFL classroom, and many researchers have been concerned with the 'teachability' of different pragmatic aspects (Kasper 1997). Bardovi-Harlig (1996) argues that researchers and teachers should work towards making the connection between pragmatics research in language teaching and the role such research should play in the language classroom. Moreover, recent curriculum innovation and revised textbooks comprise strong pragmatic components, thus bringing new demands to teachers, students, and schools. It was against this context that the present study was conceived.

\section{(cc) BY-NC-ND}


This case study is the first of a series of small-scale pedagogical interventions in the teaching of pragmatics in the Greek EFL classroom, aiming to redefine the classroom as a curricular space (Graves 2008), exploring it as a source of input in order to raise students' pragmatic awareness. Teacher talk is approached from a pragmatic viewpoint and interpreted as carrier of pragmatic meaning potential. Particular emphasis is placed on the illocutionary force of teacher questions that do not require the giving of information as a response.

\subsection{Teaching Context}

The context for my work as an English language teacher is a state High School in the prefecture of Karditsa. The communicative turn in language teaching has resulted in the Council of Europe's Common Framework of Reference for Languages, which emphasises the importance of communicative competence (defined as consisting of sociolinguistic, linguistic and pragmatic components) as a major element in any language learning and teaching (Council of Europe 2001). Within this framework, teaching foreign languages aims to facilitate the development of language skills that will enable pupils to communicate effectively in different linguistic and cultural contexts. However, students are restricted to using the English language only in the English language classroom, since English is not an official language in Greece.

It becomes clear, therefore, that, in the Greek EFL setting, the responsibility for teaching the pragmatic aspects of language use falls squarely on teachers. To accomplish this, teachers have to assume the role of "custodians of the English language and culture" in the classroom, thus bearing the responsibility for using the few weekly hours 'to teach the norms of native-speakers' English and expose learners to contextualized examples of the target language that are linguistically flawless, if communicatively efficient" (Sifakis 2009: 235). A detailed review of the relevant literature and research in the following section will reveal current demands on a pedagogic intervention, not so much with the purpose of providing learners with new information but rather to make them aware of what they know already and encourage them to use their pragmatic knowledge presumed as transferable in L2 contexts (Kasper 1997).

\section{Literature Review}

In the existing literature on teaching pragmatics in the classroom/learning context, researchers generally point out the positive impact of instruction aimed at raising learners' pragmatic awareness (Alcon 2005; Cohen \& Ishihara 
2009; Erton 2007; Guerra \& Martinez-Flor 2006; Kasper 1997; Martinez-Flor \& Fukuya 2005; Murray 2009; Rose \& Kasper 2001; Takimoto 2006; Takimoto 2009). However, a fundamental controversial question is which instructional approaches are most effective for teaching pragmatic competence in L2. Most studies comparing the effectiveness of different teaching approaches select explicit awareness-oriented instruction. Rose and Kasper (2001) argue that some form of awareness-oriented instruction is necessary because pragmalinguistic forms and sociopragmatic rules are often not salient enough for learners and that mere exposure to these rules in action does not help learners notice them. Takimoto (2009) argues that, to teach pragmatics, instruction must promote learners' conscious noticing of both the relationship between forms and meanings of target structures and the relationship between strategies for realising speech intentions, linguistic forms used to express these intentions, and social conditions governing language use. Interventional research also often includes a treatment in a teacher-fronted format, with the instructor explaining metapragmatic information about the form-function relationship between the targeted pragmatic features and highlighting the pragmatic functions of grammatical information depending on the social context (Félix-Brasdefer 2008).

For the purposes of this study, pragmatics is approached from an interpretation perspective. Wilson \& Sperber (1990) define pragmatics as the study of the general cognitive principles and abilities involved in utterance interpretation, thus aiming at describing the factors other than knowledge of sentence meaning that affect the interpretation of utterances. Leech (1983) adds that pragmatics analyses only the meaning that is publicly available for interpretation while Silverstein (2010) points out that by emphasising the pragmatic aspect of language, we tend to conceive of it as a resource for actualising event- and context-framed utterance acts.

Giving the context-dependent nature of such phenomena more centrality, Levinson (1983) views pragmatics as the study of the relations between language and context that are basic to an account of language understanding, thus being of direct practical importance in applied linguistics. The study adopts Schiffrin's (1994) view of discourse as constituted of (or consisting in) 'utterances', where utterances are considered to be inherently contextualized units of language production. Furthermore, teaching is approached as a paradigm example of Levinson's (1979) notion of language usage as activity types, according to which an activity type is a category or genre consisting of goal-defined, socially constituted, and bounded focal members. Events occurring within this category impose certain constraints on participants, setting and, above all, on the kinds of allowable contributions. 


\section{Main Aspects of Pragmatics}

\subsection{Speech Act Theory}

Speech Act theory (Austin 1962; Searle 1979; Bach and Harnish [1979]1984, amongst many others) captures the view of language as social action. Fundamental to this approach is the concept that language use involves the simultaneous performance of multiple acts. At one level, a speaker is performing a locutionary act, or producing a sentence with a particular sense and reference. Simultaneously, a speaker is performing an illocutionary act, or an act in saying. The term illocutionary act refers to the specific illocutionary force or language function associated with the uttering of particular words in a particular context. At the same time, a speaker is performing a perlocutionary act, i.e. "the bringing about of effects on the audience" (Levinson 1983: 236).

\subsection{Gricean Pragmatics}

As Schiffrin (1994), among many others, calls it, Gricean pragmatics is a contemporary version of pragmatics that focuses on meaning in context. Two concepts are central in Gricean pragmatics. The first concept is speaker meaning, suggesting a particular view of human communication that focuses on intentions. Grice (1957) separates non-natural meaning from natural meaning (natural meaning is devoid of intentionality while non-natural meaning or meaning-nn is roughly equivalent to intentional communication), thus arguing that linguistic communication occurs only when a speaker intends in using language to convey certain attitudes to his hearer and the hearer recognises what these attitudes are, based upon what has been said. This joint accomplishment between speaker and hearer in making meaning is what Thomas (1995: 208) calls "meaning in interaction", and what has been broadly meant by the term "meaning negotiation".

A main/crucial concept in Gricean pragmatics is context, viewed as a cognitive contribution to utterance interpretation. According to Schiffrin (1994), speech act theory and Gricean pragmatics view context as primarily 'knowledge', i.e. what speakers and hearers are assumed to know and how this knowledge can guide the use of language and utterance interpretation. Although a key part of such knowledge is 'knowledge of situation', both approaches fail to analyse situation, i.e. the set of social circumstances in which utterances ca be produced and interpreted as realisations of 
their underlying constitutive rules (ibid). In the same line of thought, Mey (2009a) argues that the situation creates the affordances by which the hearer is guided toward a correct interpretation of what s/he is hearing, and indeed of what $s /$ he her/himself is saying. The emphasis is placed not on describing individual speech acts but on figuring out how a particular act of language came to be used in this particular situation, in a meeting of human interactants who have a common background and try to realise a common goal (Mey, 2009b).

\subsection{Indirect Speech Acts}

Of particular importance in this study are indirect speech acts (ISA), defined by Searle (1979) as utterances in which one speech act is performed indirectly by performing another. Indirect speech acts derive their force not from their lexicosemantic buildup but from the situation in which they are appropriately uttered.

\subsection{Pragmatic Awareness}

Pragmatic awareness in part consists of illocutionary competence, that is, knowledge of acting in language, of speech acts and speech functions, and sociolinguistic competence. Fraser (1990) defines sociolinguistic competence as the ability to use language appropriately according to context while Leech (1983), integrating socio-awareness with pragmatic competence, describes sociopragmatics as the sociological interface of pragmatics, referring to the social perceptions underlying participants' interpretation and performance of communicative action.

\subsection{The Focus on Teacher Questions}

Focus on Teacher talk was based on the fact that this is the type of language use students have been exposed to and familiar with for years now. Teacher questions, in particular, can provide very illuminating examples of indirect speech acts, their illocutionary force and intentional communication. As Athanasiadou ([1991]2010) points out, questions can be classified in terms of the information which is present in the speaker's mind. 


\section{Aims}

The broader aims of the study, of which this paper is a part, are to make students aware of:

- the "reciprocal participation of speaker and hearer in the illocutionary act" (Leech 1983: 35).

- the dynamic process of making meaning (Thomas 1995).

- the pragmalinguistic and sociopragmatic resources that determine meaning construction.

However, this paper has the limited focus of an initial exploration into the classroom context of EFL in the particular local situation described above, as will become evident in the next section.

\section{Methodology}

Research in teaching pragmatics has also proposed various frameworks and guiding principles to provide support for teachers as they strive to determine the methods and materials that are most appropriate for their individual contexts. Following this line of inquiry, the present study was carried out in the form of a case study, which, as Nunan (1992) highlights, is suitable for practitioners investigating and enhancing their understanding of their own workplaces. The study focused on the classroom as a context where opportunities for raising pragmatic awareness can take place, since language classrooms are especially well suited to provide both input and interpretation, addressing problems of salience and of making language available to learners for observation (Bardovi-Harlig \& Mahan-Taylor 2003). Kasper (1997) adds that classrooms afford second language learners the opportunity to reflect on their communicative encounters and to experiment with different pragmatic options. Kasper and Rose (2002) favour focusing on institutional discourse to help demonstrate the interrelation between text and context, for example, how communicative action influences and reproduces institutional structures. Institutional talk also has the advantage of being more highly structured, routinised, and recurrent than interpersonal conversation. From a methodological perspective, the advantage lies in giving studies of institutional discourse the benefit of including an in-built control group.

As this research is primarily directed towards exploring the landscape of foreign language teaching in the context of state education, adopting the framework of Exploratory Practice seems to be most appropriate for my purposes. Allwright (2005) defines Exploratory Practice (EP) as a form of practitioner research that involves teachers and learners working together, during language lessons, to explore and develop their own understandings of their classroom lives. The 
fundamental aim of EP is to try to understand the quality of life in a given teaching/ learning situation (ibid). Zeichner and Nofke (2001) point out that practitioner research places emphasis on developing and deepening the understanding of educational practice. Exploratory Practice takes the notion of research as a supportive rather than as a parasitic activity (Allwright 2005), thus carrying out research via normal classroom activities, involving students as co-researchers.

\subsection{Participants}

This case study involved 22 students of the third grade of High School, aged 1415, taught by the researcher for 3 years so far. They have been studying English as a compulsory subject in primary and secondary education for six years and their knowledge of English is at upper-intermediate level. Upon graduation from high school, they will have completed compulsory Greek education. At the same time, they are required to reach level B2 of language proficiency in English (Council of Europe 2001). All students use the same textbook (Think Teen, published by the Pedagogical Institute, available online at http://www.pischools.sch.gr/gymnasio/aggl_c/math.pdf ).

Since explicit information regarding pragmatics is not included in this textbook but is included as a learning objective of the curriculum (Pedagogical Institute 2003), it was deemed necessary that the researcher complement the textbook with a pragmatics component.

\subsection{Task Design and Implementation}

This group of students has two 40-minute English teaching sessions twice a week. For the purposes of this study, 4 lessons were videotaped and thoroughly assessed by the researcher. From these lessons, seven pieces were isolated to be utilised in the study. The pieces contained pragmatic acts involving teacher questions that do not require the giving of information as a response. The teacher questions selected fell into two categories: Indirect Requests and Rhetorical Questions. Selection was based on Athanasiadou's ([1991]2010) argument that all questions of indirect requests leave the initiative with the respondents, placing them at an advantage and emphasising the respondents' power to choose. So, the dominant role is transferred to the respondents, thus rendering the teacher less authoritative and creating a relaxed and more productive classroom atmosphere. Selection of rhetorical questions was made in terms of their multiple functions: in a rhetorical question a constituent is given emphatic prominence and gets a universally valid touch; in asking a rhetorical question, a speaker anticipates consensus on the part of the hearer. 
Instruction was in English, but tasks were translated into Greek when students had some trouble with task performance. The study was completed in two weeks (four lessons). The instructional treatment was as follows. First, the class was provided with explicit instruction on Indirect Speech Acts. Several examples were used, starting with Searle's widely used example "Can you pass me the salt?" to demonstrate the different illocutionary forces an interrogative linguistic form can have in real life.

Upon completion of the tutorial, the students were involved in two awareness-raising tasks to draw their conscious attention to and deepen their understanding of how pragmatic considerations can influence language use. Task design was based on input enhancement defined by Sharwood Smith (1993) as any pedagogical intervention used to make specific target features of the input more salient as an effort to draw learners' attention to these features. Takimoto (2006) argues that the target pragmatic features can be best learned when taught explicitly together with some sort of input enhancement activities. Defined by Ellis (2008) as 'knowledge about the L2', explicit knowledge consists of analysed knowledge and metalanguage. The former refers to that knowledge about L2 items and structures of which the learner is aware but not necessarily conscious. The latter is 'the language used to analyze or describe a language' (Richards, Platt and Weber 1985 as cited in Ellis 2008) must be learnt through instruction or observation. DeKeyser (1995) adds that explicit learning occurs with concurrent awareness of what is being learned.

In more detail, students were asked to watch one videotaped pragmatic act at a time. Immediately after watching it, they were provided with a scripted version of the situations (see Table 1 below) and a list of illocutionary forces to match with it (see Table 2 below):

They were then required to fill in their verbal reports considering the several pragma-linguistic and socio-pragmatic resources (see Table 3 below) that had affected their interpretation of each situated utterance.

During the task, the teacher provided explicit feedback in the form of metalinguistic information on these resources.

\subsection{Data Collection}

Data collection was carried out by monitoring lessons (reflective lesson plans), reflecting on students' choices, and reflecting on students' reflections noted down retrospectively on their verbal reports. Verbal reports were used to obtain data that described the learning event near the moment it occurred. According to Cohen (1996), verbal reports can provide data that reflect some retrospective self-observation: the inspection of specific language behaviour in actual instances of language use. 
Table 1.

Scripted version of the situations

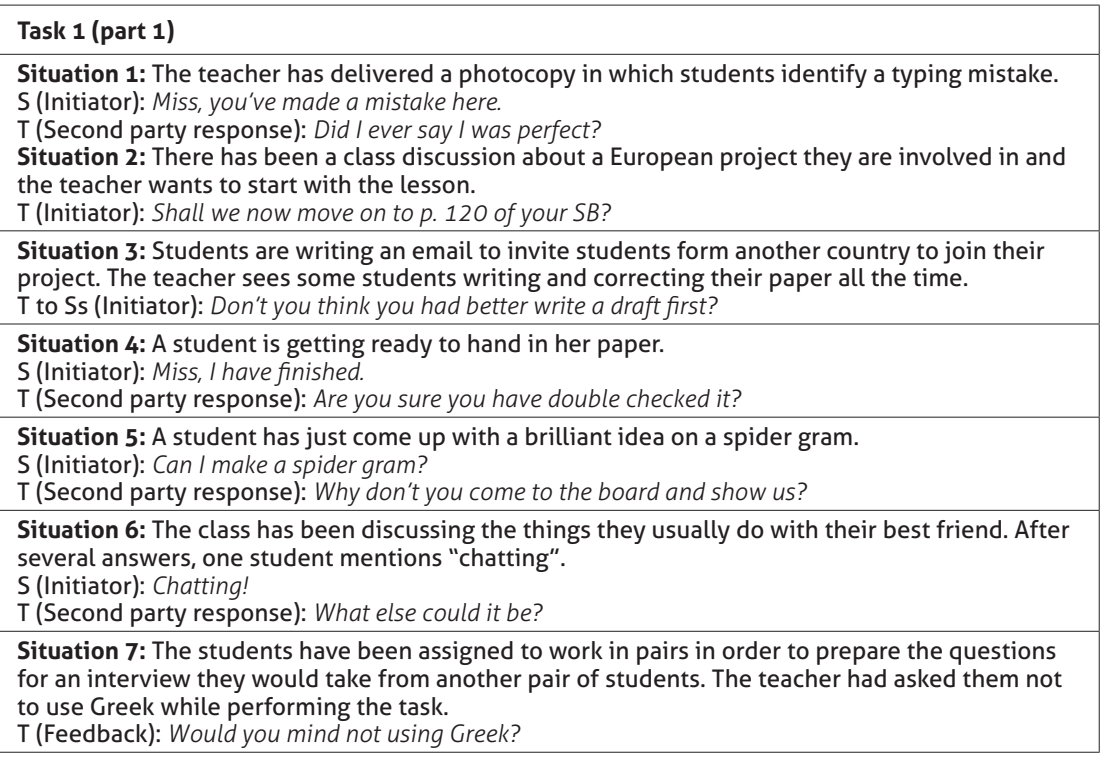

Based on Sequences of predictable IRF (initiation-response-feedback) discourse chains (Sinclair and Coulthard 1975, as cited in Cullen 1998)

Table 2.

Illocutionary forces

\begin{tabular}{|l|}
\hline Task $\mathbf{1}$ (part 2) \\
\hline Illocutionary Force \\
\hline Suggestion \\
Invitation \\
Advice \\
Apology \\
Request \\
Suggestion \\
Agreement \\
\hline
\end{tabular}

Table 3.

Pragmalinguistic and Sociopragmatic resources

\begin{tabular}{|l|}
\hline Task 2 \\
\hline Pragmalinguistic and Sociopragmatic resources \\
\hline Cooperation (Grice 1975) \\
Politeness (Leech 1983) \\
Relevance (Wilson \& Sperber 1990) \\
Shared situational knowledge (Mey 2009a). \\
Shared knowledge of the scene around them (Clark 2009). \\
Common Ground (Stalnaker 2002) \\
Intonation (Austin 1962) \\
Nonverbal means such as gestures and body movements (Mey 2009b). \\
Facial expressions, voice quality (Haviland 2009). \\
\hline
\end{tabular}




\subsection{Findings}

The data yielded by verbal reports are presented and critically analysed below:

Students faced no difficulty in identifying the matching illocutionary force to each situated utterance. The factors they identified as assisting them in meaning construction were as follows:

Table 4.

Results

\begin{tabular}{|l|}
\hline Results \\
\hline Cooperation $\quad 95 \%$ \\
Politeness $\quad 95 \%$ \\
Relevance $95 \%$ \\
Shared situational knowledge $\quad 100 \%$ \\
Shared knowledge of the scene around them $\quad 100 \%$ \\
Common Ground $\quad 100 \%$ \\
Intonation $53 \%$ \\
Nonverbal means such as gestures and body movements $\quad 69 \%$ \\
Facial expressions, voice quality $69 \%$ \\
\hline
\end{tabular}

\section{Discussion}

Shared situational knowledge, shared knowledge of the scene around them, and common ground (100\%) were identified as the most important factors determining pragmatic interpretation. In their verbal reports students mentioned facts such as the teacher's regular use of certain expressions and her familiar teaching attitude.

Politeness, cooperation, and relevance were considered highly important by an overwhelming majority of students (95\%). Their verbal reports emphasised the use of the expressions "Why don't you..?", "Shall we..?" and "Would you mind..?" and they also mentioned that they were attentive and cooperative.

A considerable percentage $(69 \%)$ of the students stated that nonverbal means such as gestures, body movements, facial expressions and voice quality helped them in recognising speaker intention. They attributed it to the fact that they had not been exposed to analysing such features before.

Only half of the students (53\%) stated that interpretation was facilitated by intonation. They explained that lack of awareness of the significance of intonation was the reason for this. This entails that the class should be allowed opportunities to practice on intonation and its functions. 


\section{Conclusions}

This study was designed to address the issue of raising pragmatic awareness through teacher illocutionary acts. The results of the study, consistent with previous research, indicate that explicit instruction was effectively combined with awareness-raising tasks where an emphasis was placed on

-raising awareness of speaker intention

-raising awareness of the pragmalinguistic and sociopragmatic resources determining meaning construction.

An initial but important conclusion to be drawn, however, is that we can raise learners' pragmatic awareness on condition that we adhere to Austin's suggested moral to "engage in elucidating the total speech act in the total speech situation" (1962: 147)

\section{Implications for Future Research}

Although the study yielded important findings, it is clear that no generalisations can be drawn based on eight lessons and on this restricted group of 22 students. Since, however, these students have gained from explicit instruction combined with awareness-raising tasks, an interesting future implication would stress the necessity of complementing Greek state EFL coursebooks with a pragmatics component. A second important implication would emphasise Greek EFL teachers' potential to assume the role of "custodians of the English language and culture" in the classroom (Sifakis 2009: 235). Last but not least, another recommendation for future practice would focus on involving students as coresearchers in practitioner research to enhance motivation and classroom interaction. 


\section{References}

Alcon, E. 2005. Does instruction work for learning pragmatics in the EFL context? System 33 (3): 417-435.

Allwright, D. 2005. Developing Principles for Practitioner Research: The Case of Exploratory Practice. The Modern Language Journal 89(3): 353-366.

Athanasiadou, A. [1991] 2010. The Discourse Function of Questions. Pragmatics 1: $107-122$.

Austin, J.L. 1962. How to Do Things with Words. Oxford: Clarendon Press.

Bach, K. and Harnish, R.M. [1979] 1984. Linguistic communication and speech acts. Cambridge, MA: MIT press.

Bardovi-Harlig, K. 1996. Pragmatics and Language teaching: Bringing pragmatics and pedagogy together. In L.F. Boufon (ed.), Pragmatics and language learning, vol 7. Urbana, IL: University of Illinois at UrbanaChampaign, 21-39.

Bardovi-Harlig, K. and Mahan-Taylor, R. (eds.). 2003. Teaching pragmatics. Washington DC: Office of English Programs, U.S. Department of State. Retrieved 30 March 2010 from http://exchanges.state. gov/education/engteaching/ pragmatics.htm.

Clark, H.H. 2009. Context and Common Ground. In J. Mey (ed.), Concise Encyclopedia of pragmatics. Oxford: Elsevier, 116-119.

Cohen, A. 1996. Verbal Reports as a Source of Insights into Second Language Learner Strategies. Applied Language Learning 7(18 2): 5-24. 
Cohen, A.D. and Ishihara, N. 2009. New Insights into Teaching Pragmatics in the ESL/ EFLClassroom. Retrieved 08 April 82010 from http://www.tc.umn.edu/ adcohen/ documents/2009-Cohenandlshihara-TchgPragintheESLClsrm_000.doc

Council of Europe 2001. Common European Framework of Reference for

Languages: Learning, Teaching and Assessment. Strasbourg. Retrieved 29 March 2010 from http://www.coe.int/T/DG4/Linguistic/Source/Framework_EN.pdf.

Cullen, R. 1998. Teacher talk and the classroom context. ELT Journal 52(3): 179187.

DeKeyser, R. 1995. Learning Second Language Grammar rules: An Experiment with a Miniature Linguistic System. Studies in Second Language Acquisition 17 (3): 379-410.

Ellis, R. 2008. Explicit knowledge and second language learning and pedagogy. In J. Cenoz and N.H. Hornberger (eds.), Encyclopedia of Language and Education 6: 143-153.

Erton, I. 2007. Applied Pragmatics and Competence Relations in Language Learning and Teaching. Journal of Language and Linguistic Studies 3(1): 59-71.

Félix-Brasdefer, J.C. 2008. Pedagogical Intervention and the Development of Pragmatic Competence in Learning Spanish as a Foreign Language. Issues in Applied Linguistics 16(1): 49-84.

Fraser, B. 1990. Perspectives on Politeness. Journal of Pragmatics 14 (2): 219236.

Graves, K. 2008. The language curriculum: A social contextual perspective. Language Teaching 41(2): 147-181.

Grice, H.P. 1957. Meaning. The Philosophical Review 66 (3): 377-388.

Grice, H.P. 1975. Logic and conversation. In P. Cole and J. Morgan (eds.), Syntax and Semantics 3: Speech acts. New York: Academic Press, 41-58.

Guerra, A. and Martinez-Flor, A. 2006. Is teaching how to suggesta good suggestion? An empirical study Based on EFL learners' accuracy and appropriateness when making suggestions. Porta Linguarum 5: 91-108. 
Haviland, J.B. 2009. Cultural and Social Dimension of Spoken Discourse. In J. Mey (ed.), Concise Encyclopedia of Pragmatics. Oxford: Elsevier, 170-173.

Kasper, G. 1997. Can pragmatic competence be taught? Retrieved 29 March 2010 from http://www.nflrc.hawaii.edu/networks/NW06/default.html.

Kasper, G. and Rose, K.R. 2002. Pragmatic Development in a Second Language. Oxford: Blackwell.

Leech, G. 1983. Principles of Pragmatics. London: Longman.

Levinson, S.C. 1979. Activity types and language. Linguistics 17: 365-399.

Levinson, S.C. 1983. Pragmatics. Cambridge: Cambridge University Press.

Martínez-Flor, A. and Fukuya, Y.J. 2005. The effects of instruction on learners' production of appropriate and accurate suggestions. System 33: 463-480.

Mey, J. 2009a. Pragmatic Acts. In J. Mey (ed.), Concise Encyclopedia of Pragmatics. Oxford: Elsevier, 747-753.

Mey, J. 2009b. Pragmatics: An Overview. In J. Mey (ed.), Concise Encyclopedia of Pragmatics. Oxford: Elsevier, 786-797.

Murray, N. 2009. Pragmatics, awareness raising, and the Cooperative Principle. ELT Journal Advance Access. Retrieved 29 March 2010 from http://eltj.oxfordjournals. org/cgi/content/abstract/ccp056.

Nunan, D. 1992. Research Methods in Language Learning. Cambridge: Cambridge University Press.

Pedagogical Institute 2003. Cross Curricular/Thematic Framework (C.C.T.F). Retrieved 29 March 2010 from http://www.pi- schools.gr/lessons/english/ pdf/14depps_XenonGlosson-Agglika.pdf.

Rose, K.R. and Kasper, G. (eds.). 2001. Pragmatics in language teaching. Cambridge: Cambridge University Press.

Schiffrin, D. 1994. Approaches to Discourse. Malden, Massachusetts: Blackwell.

Searle, J.R. 1979. Expression and Meaning: Studies in the Theory of Speech Acts. Cambridge: CUP. 
Sharwood Smith, M. 1993. Input enhancement in instructed SLA: Theoretical bases. Studies in Second Language Acquisition 15 (2): 165-179.

Sifakis, N. 2009. Challenges in teaching ELF in the periphery: the Greek context. ELT Journal 63(3): 230-237.

Silverstein, M. 2010. "Direct" and "indirect" communicative acts in semiotic perspective. Journal of Pragmatics 42:337-353.

Stalnaker, R. 2002. Common Ground. Linguistics and Philosophy 25: 701-721.

Takimoto, M. 2006. The effects of explicit feedback and form-meaning processing on the development of pragmatic proficiency in conscious-raising tasks. Science Direct 34(4): 601-614.

Takimoto, M. 2009. The Effects of Input-Based Tasks on the Development of Learners' Pragmatic Proficiency. Applied Linguistics Advance Access 30(1): 1-25.

Thomas, J. 1995. Meaning in Interaction: An Introduction to Pragmatics. London: Longman.

Wilson, D. and Sperber, D. 1990. Outline of Relevance Theory. Hermes 5: 35-56.

Zeichner, K. and Nofke, S. 2001. Practitioner research. In V. Richardson (Ed.), Handbook of Research on teaching. Washington, DC: AERA, 298-330. Retrieved 02 April 2010 from http://ia.fc.ul.pt/redeic/textos\%20teoricos/Zeichner-Nofke.pdf. 
Major Trends in Theoretical and Applied Linguistics 